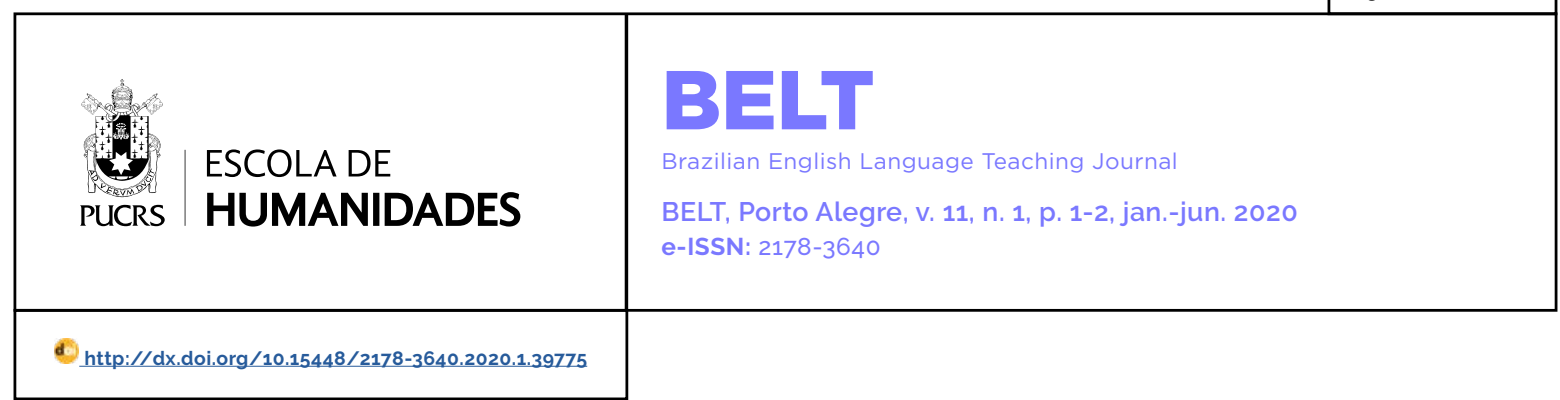

\title{
English as a second language in its different contexts of study
}

O inglês como segunda lingua em seus diferentes contextos de estudo

\section{Cristina Becker Lopes \\ Perna ${ }^{1,2}$ \\ orcid.org/0000-0002-9638-1180 \\ cperna@pucrs.br}

\section{Aline Jéssica Antunes ${ }^{1}$ \\ orcid.org/0000-0001-5337-3458 aline.antunes@edu.pucrs.br \\ Camille Schneider \\ Santos ${ }^{1}$ \\ orcid.org/0000-0001-5533-6108 camille.s@edu.pucrs.br}

Received on: Dec. $18^{\text {th }}, 2020$ Accepted on: Dec. $18^{\text {th }}, 2020$ Published on: Jan. $11^{\text {th }}, 2021$

\section{(c) (i)}

Artigo está licenciado sob forma de uma licença Creative Commons Atribuição 4.0 Internacional.
It is an honor to announce the most recent edition of the Brazilian English Language Teaching Journal (BELT). The latest volume is comprised of three original articles, one review and one didactic sequence and these vary in range from topics such as reflections on translation work and teacher training, register variation in online texts and literacy studies. In the following paragraphs, you will find a short summary of the papers presented in the $11^{\text {th }}$ volume of BELT:

Kirch's paper is an analysis of the reflections brought about from a pedagogical project executed in a Brazilian University, in a class of Portuguese and English Language studies, with a group of teachers-intraining, particularly as it relates to the career of translators. The aim of the project was to give the future English teachers different perspectives and it succeeded in that as, in the end, some participants alluded that their future may not be in teaching. Further, the paper acknowledged that this activity allowed students to realize that there are different opportunities in their future careers.

In their article, Hitotuzi and Ferreira acknowledge that even though the method of Synthetic Phonics is employed in anglophone countries with frequency when it comes to the reading ability of speakers' mother tongue, there is a lack of studies in regard to its use in the learning of reading in an additional language. It is for that reason that the authors sought to conduct a case study of early literacy employing the Synthetic Phonic Method (SPM). After data collection and careful analysis, it was concluded that the SPM is indeed successful in teaching Brazilian children to read in English.

In "Good Practices in Language Education: the contributions of Bem Legal Journal to Language Teacher Education", the authors Welp, Sarmento, Selbach and Ramos explore the necessity of a space for teachers to spread their experiences and in that way contribute to the education of future teachers. This is done by presenting the history of Bem Legal Journal, as well as its inner workings and an overview of its publications. It is made clear in words and graphics that the Journal's long-standing history should and does speak for itself as it bestows language educators with the benefits of the collaboration of teachers and pedagogues. 
Contributing to the field of Applied Sociolinguistics, the didactic sequence of this volume presents important research on the teaching of informal language through the sitcom genre. After realizing the shortage of studies that have been done exploring Informal English through audiovisual genres, the authors, Lima and Senefonte, hope to expand the research available in order to help educators in this aspect of language teaching and learning.

Last, but not least, is the review of the book by Biber and Egbert (2018), entitled Register Variation Online (CUP). According to Goulart, the study describes register variation in the searchable web, i.e. texts that are publicly available when doing a Google search. In her review, the author describes each chapter of the book before she presents her evaluation, concluding that Biber and Egbert do a great job of describing registers available online, discussing how the different communicative purposes motivate language variation in the use of grammar features, and keywords.

We are deeply thankful for the authors' contributions to this volume of BELT and for all the research that was put into their articles. We wish that you enjoy the reading, and that this collection of papers helps you as a language learner, teacher and researcher.

\author{
Mailing address \\ Cristina Becker Lopes Perna \\ Avenida Ipiranga, 6681 \\ Partenon, 90619-900 \\ Porto Alegre, RS, Brasil.
}

